\title{
Identification of Pasteurella multocida tryptophan synthase $\beta$-subunit by antisera against strain P1059
}

\author{
Peter E. Jablonski, ${ }^{1}$ Lynn M. Jablonski, ${ }^{2} \dagger$ Oscar Pintado, ${ }^{3}$ \\ Namalamar Sriranganathan ${ }^{3}$ and Carolyn J. Hovde ${ }^{2}$ \\ Author for correspondence: Carolyn J. Hovde. Tel: +1208 885 5906. Fax: +12088856518. \\ e-mail: cbohach@uidaho.edu
}

1 Department of Biological Sciences, Northern Illinois University, DeKalb, IL 60115-2861, USA

2 Department of Microbiology, Molecular Biology and Biochemistry, University of Idaho, Moscow, ID 83844-3052, USA

3 Department of Biosciences and Pathobiology, Virginia Maryland Regional College of Veterinary Medicine, Virginia Polytechnic Institute and State University, Blacksburg, VA 24061-0442, USA

\begin{abstract}
Pasteurella multocida strain P1059 is a highly virulent bacterium which causes fowl cholera in turkeys and chickens. A genomic library of P. multocida P1059 DNA was constructed using pUC19, expressed in Escherichia coli DH5 $\alpha$, and screened with chicken antisera generated against P. multocida P1059. Twelve out of the $\mathbf{4 1 0 0}$ clones screened were immunoreactive. Plasmids isolated from these twelve clones were transformed into E. coli CSR603 for maxicell analysis. Five proteins, with molecular masses of 34, 37, 43, 46 and $55 \mathrm{kDa}$, were expressed. Further work focused on the $43 \mathrm{kDa}$ protein because it was expressed at levels detectable by SDS-PAGE and immunoblot analysis. The nucleotide sequence of the $1.8 \mathrm{kbp}$ insert containing the gene encoding this protein was determined. The sequence contained three open reading frames (ORFs). The first ORF (ORF1) did not appear to code for any known protein. The second ORF (ORF2) encoded a protein of 403 amino acids (43662 Da). The deduced amino acid sequence showed $77 \%$ identity ( $84 \%$ similarity) with the tryptophan synthase $\beta$ subunit (TrpB) of Salmonella typhimurium and Vibrio parahaemolyticus. The eight conserved regions of TrpB are observed in the $P$. multocida enzyme, including the conserved lysine (Lys-88) and consensus sequence (GGGSNA) implicated in pyridoxal phosphate binding. The expression and identity of the $P$. multocida TrpB were confirmed by complementation studies using E. coli W3110 tnaA2 trpB9578. The third ORF (ORF3) consisted of the first 77 nucleotides of the gene encoding the $\alpha$-subunit of tryptophan synthase (trpA), and overlapped the 3'-end of trpB by 14 nucleotides. The deduced amino acid sequence of the 77 nucleotides of the $P$. multocida TrpA had $68 \%$ identity ( $92 \%$ similarity) with the analogous region of TrpA from Klebsiella aerogenes (K. pneumoniae).
\end{abstract}

Keywords: Pasteurella multocida, tryptophan synthase, nucleotide sequence analysis

\section{INTRODUCTION}

Pasteurella multocida P1059 is one of a number of strains which can cause fowl cholera, a highly contagious disease in chickens and turkeys (Rimler \& Rhoades, 1989). The molecular basis of the pathogenesis of $P$. multocida is not well understood, although many putative virulence

†Present address: Department of Biological Sciences, Northern Illinois University, DeKalb, IL 60115-2861, USA.

The GenBank accession number for the nucleotide sequence reported in this paper is U22344. factors such as capsule (Hansen \& Hirsh, 1989; Snipes et al., 1987), outer-membrane proteins (Lu et al., 1991a, b; Truscott \& Hirsh, 1988), lipopolysaccharide (Rhoades \& Rimler, 1987; Wijewardana et al., 1990), siderophores (Hu et al., 1986) and toxins (Rhoades \& Rimler, 1988) have been reported. Several $P$. multocida genes have been cloned in recent years, including adenylate cyclase (Mock et al., 1991), P. multocida toxin (tox A) (Lax et al., 1990; Petersen, 1990; Petersen \& Foged, 1989), a repressor of tox $A$ termed TxaR (Petersen, 1990), the aro $A$ gene (Homchampa et al., 1992), and most recently two genes, one of which encodes for a protein antigenically related to porin H (Manoha et al., 1994). Despite this progress, gene 
structure in Pasteurella has not been well investigated. For example, a conserved consensus sequence for the ribosome-binding site is unknown. Further characterization of a variety of $P$. multocida genes will undoubtedly reveal patterns to help elucidate gene regulation and identify potential new virulence factors.

The purpose of this study was to clone and express in vivoexpressed antigenic proteins of P. multocida P1059 in the hope of identifying potential virulence factors. A number of the 4100 clones analysed reacted with chicken antiserum directed against $P$. multocida P1059. We focused on a $43 \mathrm{kDa}$ protein because of its high expression in an Escherichia coli maxicell system. The gene encoding this protein was cloned, sequenced, and identified as encoding for the $\beta$ subunit of tryptophan synthase ( $\operatorname{TrpB}$ ) based on sequence analysis and complementation studies with an E. coli $\operatorname{tr} \not B$ auxotroph.

Tryptophan synthase was one of the first enzymes of the tryptophan pathway to be extensively studied. The enzyme catalyses the terminal step in the biosynthesis of tryptophan from L-serine and indoleglycerol phosphate and is a tetramer comprised of two $\alpha$ subunits coded for by the $\operatorname{tr} p A$ gene and a $\beta$ dimer coded for by the $\operatorname{tr} p B$ gene. The $\beta$ subunit has two binding sites for pyridoxal phosphate and also two independent sites to which the $\alpha$ subunit can bind (Creighton \& Yanofsky, 1966; Wilson \& Crawford, 1965). This enzyme has been used to investigate evolutionary relationships between microorganisms as there is a high degree of similarity among tryptophan synthases from diverse micro-organisms, especially within the $\beta$ subunit. Here we report the cloning and nucleotide sequence analysis of the $\operatorname{tr} p B$ locus from $P$. multocida and show that it, too, is similar to other $\operatorname{trp} B$ genes sequenced to date.

\section{METHODS}

Bacterial strains. P. multocida strain P1059 (ATCC 15742) was obtained from the collection of Dr Gordon Carter (Virginia Tech, Blacksburg, VA, USA). E. coli strains DH5 $\alpha$ and CSR603 were obtained from the collection of $\mathrm{Dr}$ Scott Minnich (University of Idaho, Moscow, ID, USA). E. coli W3110 tna A2 $\operatorname{trpB9578}$ was a kind gift of Dr Charles Yanofsky (Stanford University, Stanford, CA, USA).

Preparation of $\boldsymbol{P}$. multocida. P. multocida $\mathrm{P} 1059$ was grown for $18 \mathrm{~h}$ at $37^{\circ} \mathrm{C}$ with shaking (150 r.p.m.) in brain heart infusion broth (BHIB). An aliquot $(0 \cdot 1 \mathrm{ml})$ was used to inoculate $10 \mathrm{ml}$ fresh BHIB. Cells were harvested in late-exponential phase (approximately 425 Klett units, filter no. 54, green) by centrifugation at $7000 \mathrm{~g}$ for $10 \mathrm{~min}$ at $22{ }^{\circ} \mathrm{C}$, and were washed twice in phosphate-buffered saline (PBS) $(10 \mathrm{mM}$ potassium phosphate, $\mathrm{pH} 7 \cdot 0$, containing $10 \mathrm{mM} \mathrm{NaCl}$ ). The cell pellet was resuspended in $10 \mathrm{ml}$ PBS and inocula were made by serial dilutions in the same buffer.

Preparation of chickens and chicken antisera. Ten-week-old specific pathogen-free (SPF) white leghorn chickens were purchased from SPAFIS (Norwich, CT, USA). Each group was kept in isolation. However, within a group, birds were free to interact for the duration of the experiment. Birds were housed in temperature-controlled rooms at $20^{\circ} \mathrm{C}$ and provided water and feed ad libitum. Chickens were immunized in the wing vein three times, $10 \mathrm{~d}$ apart, with an average dose of $3.6 \times 10^{3}$ c.f.u. of live P. multocida P1059. Two birds in each group received $200 \mu \mathrm{l}$ of PBS as a negative control. To validate infection by $P$. multocida, samples were taken aseptically from the liver, heart, and pericardial fluid. To validate septicaemia, samples were taken from the bone marrow of the femur. The presence of $P$. multocida was confirmed by Gram staining, characteristic colony morphology on $5 \%(\mathrm{v} / \mathrm{v})$ blood agar, lack of growth on MacConkey agar, and nonfermentative API test strips (bioMérieux Vitek).

Serum was collected from each chicken prior to the first immunization (prebleed) and $10 \mathrm{~d}$ after the final immunization. To separate the serum from other components of the blood, the samples were centrifuged at $3000 \mathrm{~g}$ for $25 \mathrm{~min}$ at $4{ }^{\circ} \mathrm{C}$. Serum was removed, aliquoted, and stored at $-80^{\circ} \mathrm{C}$. Once thawed, serum was stored at $4{ }^{\circ} \mathrm{C}$.

Preparation of in vivo-grown P. multocida P1059. In vivogrown $P$. multocida $\mathrm{P} 1059$ cells were harvested from the blood of chickens by differential centrifugation, using a modification of the method of Rimler \& Rhoades (1981). Briefly, 14-16-weekold white leghorn chickens were inoculated intravenously with $10^{4}$ c.f.u. of $P$. multocida in the wing vein. At $20-24 \mathrm{~h}$ postinoculation they were bled aseptically via the jugular vein into a syringe containing appropriate amounts of an anticoagulant solution (ACD solution, Rimler \& Rhoades, 1981). Plasma was collected by centrifugation $\left(600 \mathrm{~g}\right.$ for $30 \mathrm{~min}$ at $\left.4{ }^{\circ} \mathrm{C}\right)$. The process was repeated three times. The final supernatant was aspirated and $20 \mathrm{ml}$ was dispensed into sterile round-bottom Corex tubes $(25 \mathrm{ml})$, and centrifuged at $10000 \mathrm{~g}$ for $60 \mathrm{~min}$ at $4{ }^{\circ} \mathrm{C}$. The supernatant was discarded and the bacterial pellet was resuspended in $20 \%$ sucrose/Tris solution $[0.025 \mathrm{M}$ Tris $/ \mathrm{HCl}$ ( $\mathrm{pH} 7.0$ ) containing $20 \%(\mathrm{w} / \mathrm{v}$ ) sucrose]. The suspension was layered onto ice-cold $30 \%$ sucrose/Tris solution in new Corex tubes and centrifuged at $200 \mathrm{~g}$ for $30 \mathrm{~min}$ at $4{ }^{\circ} \mathrm{C}$. The bacteria remained in the upper $20 \%$ sucrose layer and were recovered by centrifugation at $10000 \mathrm{~g}$ for $10 \mathrm{~min}$ at $4{ }^{\circ} \mathrm{C}$ in $1.5 \mathrm{ml}$ microcentrifuge tubes. The cells were confirmed to be $P$. multocida as described above and were stored at $-80^{\circ} \mathrm{C}$.

Construction and screening of a P. multocida P1059 genomic library. Genomic DNA was isolated from P. multocida P1059 according to Murray \& Thompson (1980). The DNA was digested with Sau3A and resolved by electrophoresis through $0.7 \%(\mathrm{w} / \mathrm{v})$ low-melting-point agarose. Fragments $1-10 \mathrm{~kb}$ in size were excised, heated for $15 \mathrm{~min}$ at $65^{\circ} \mathrm{C}$, and mixed with Bam HI-linearized, dephosphorylated pUC19 at a vector to insert ratio of $1: 1$. The mixture was incubated at $37^{\circ} \mathrm{C}$ for $15 \mathrm{~min}$ and then ligated using $\mathrm{T}_{4}$ DNA ligase overnight at $22^{\circ} \mathrm{C}$. The mixture was used to transform $E$. coli $\mathrm{DH} 5 \alpha$ by the method of Hanahan (1983). A total of 4100 clones were selected on LB plates containing $100 \mu \mathrm{g} \mathrm{ml}^{-1}$ stock of Bluo-gal (GIBCO/BRL). Each clone contained an average insert size of $4 \mathrm{kbp}$, representing over $99 \%$ of the genome (based on a genome size of $1 \cdot 2-2 \cdot 2 \times 10^{6} \mathrm{bp} ;$ Pohl, 1981). Individual clones were grown overnight at $37^{\circ} \mathrm{C}$ in Terrific Broth (TB; Ausubel et al., 1989), harvested, and stored at $-80^{\circ} \mathrm{C}$ in $\mathrm{TB}$ containing $15 \%(\mathrm{v} / \mathrm{v})$ glycerol. The genomic library was also stored as a pooled plasmid preparation at $-20^{\circ} \mathrm{C}$. The library was screened with chicken anti-P. multocida P1059 antisera (that had been adsorbed with $E$. coli $\mathrm{DH} 5 \alpha$ in order to distinguish cross-reactive colonies from those expressing recombinant proteins) by colony blot analysis (Sambrook et al., 1989). Clones which reacted three times were considered positive for the in vivo expression of antigens from $P$. multocida P1059. Plasmids were isolated from antibody-reactive clones as described by Sambrook et al. (1989). 
To confirm that clones originated from $P$. multocida, Southern blotting was performed by standard procedures (Ausubel $e t a l$., 1989).

Maxicell analysis. Preparation of electrocompetent E. coli cells and transformation by electroporation with a Bio-Rad Gene Pulser apparatus were as described by Dower et al. (1988). We selected one of the isolated plasmids, pOP43-2G, for further analysis because it contained an insert encoding high levels of a $43 \mathrm{kDa}$ protein. E. coli CSR603 was transformed with pOP43$2 \mathrm{G}$ and plated on LB-Amp plates. Ampicillin-resistant colonies were selected and the presence of the plasmid confirmed. A single colony was used to inoculate M63-glucose medium (Sambrook et al., 1989) supplemented with $1 \%$ (w/v) Casamino acids (Difco Laboratories) and $100 \mu \mathrm{g}$ ampicillin $\mathrm{ml}^{-1}$. The culture was incubated at $37^{\circ} \mathrm{C}$ overnight with shaking and used to inoculated $10 \mathrm{ml}$ of the same medium and was grown until mid-exponential phase (approximately 100-110 Klett units), transferred to a plastic Petri plate $(10 \mathrm{ml} \times 150 \mathrm{~mm})$ and irradiated with a total of $5300 \mu \mathrm{J}$ of UV energy (Stratalinker UV Crosslinker; Stratagene). Irradiated cultures were allowed to recover for $30 \mathrm{~min}$ at $37^{\circ} \mathrm{C}$ prior to adding cycloserine (final concentration $200 \mu \mathrm{g} \mathrm{ml}^{-1}$ ), and were incubated overnight at $37^{\circ} \mathrm{C}$ with shaking. Cells were harvested and resuspended in SDS-PAGE sample buffer and analysed on SDS polyacrylamide gels $(12 \%, \mathrm{w} / \mathrm{v}$, acrylamide) as described below.

Gel electrophoresis and Western blotting (immunoblotting). Denaturing SDS-PAGE was carried out as described by Laemmli (1970). Proteins were detected by staining with Coomassie Blue R-250. Immunoblot analysis was performed according to Towbin et al. (1979) using alkaline-phosphataseconjugated anti-chicken rabbit IgG (Sigma), as described by Bollag \& Edelstein (1991).

DNA sequencing and analysis. The sequence of both strands of the 1830 bp insert of pOP43-2G was determined from denatured double-stranded templates by the dideoxynucleotide chaintermination method (Sanger et al., 1977) with Sequenase polymerase (version 2.0; USB) and $5^{\prime}-\left[\alpha^{35}{ }^{35}\right.$ S thio-dATP (New England Nuclear; $\left.1156 \mathrm{Ci} \mathrm{nmol}^{-1}, 42 \cdot 8 \mathrm{TBq} \mathrm{nmol}^{-1}\right)$. Oligonucleotides were purchased from USB ( -40 and reverse primer for $\mathrm{M} 13 \mathrm{mp} 19$ ) or synthesized by Oligos, Etc (Wilsonville, OR, USA) complementary to sequences internal to the insert. All reactions were carried out according to the manufacturer's protocols. DNA and protein sequences were compared with nonredundant DNA sequence and protein databases with the programs BLASTN and BLASTP (Altschul et al., 1990), respectively, through the electronic mail server at the National Center for Biotechnology Information (NCBI). Sequence data were further analysed using the PC-Gene sequence analysis programs (IntelliGenetics, Mountain View, CA, USA).

Complementation of $E$. coli trpB mutant strain. E. coli W3110 tna $A 2 \operatorname{trp} B 9578$ was made electrocompetent and transformed with pOP43-2G by electroporation as described above. Transformants were plated on M63-glucose supplemented with $1 \%$ $(\mathrm{w} / \mathrm{v})$ Casamino acids and thiamin $\left(1 \mu \mathrm{g} \mathrm{ml}^{-1}\right)$ with or without tryptophan $\left(40 \mu \mathrm{g} \mathrm{ml}^{-1}\right)$ and ampicillin $\left(100 \mu \mathrm{g} \mathrm{ml}^{-1}\right)$ and incubated overnight at $37^{\circ} \mathrm{C}$. Ampicillin-resistant, tryptophanindependent colonies were selected and assayed for the presence of pOP43-2G. Plasmid pUC19 served as a negative control.

\section{RESULTS AND DISCUSSION}

In an effort to detect in vivo-expressed antigens of $P$. multocida we created a plasmid-based genomic library and examined 4100 clones, of which 12 reacted with chicken

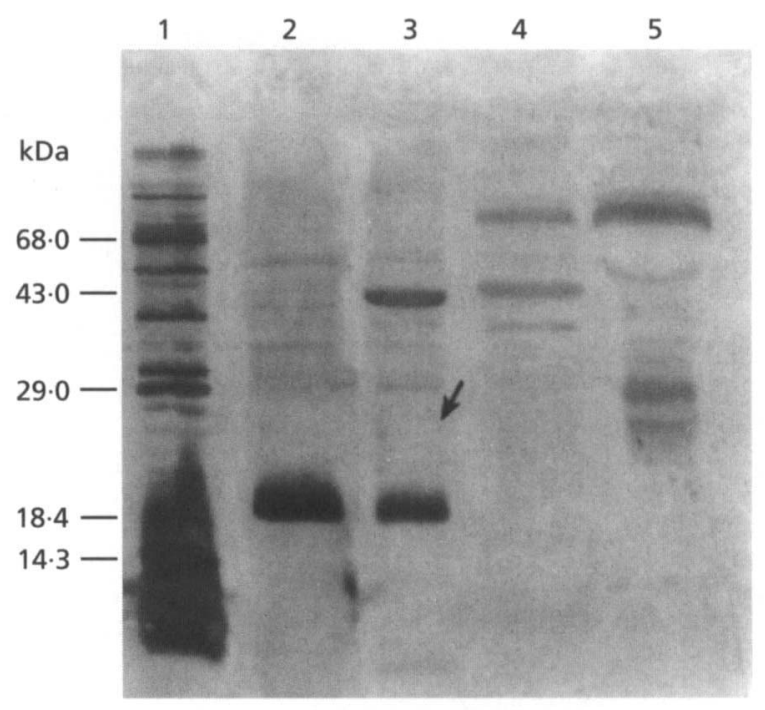

Fig. 1. Detection of $P$. multocida immunoreactive antigens by immunoblot analysis. Lanes: 1 , in vitro-grown $P$. multocida P1059; 2, E. coli CSR603; 3, E. coli CSR603 containing pOP43-2G; 4 , in vivo-grown $P$. multocida P1059; 5 , normal chicken serum. The membrane was processed as described in Methods. The molecular mass standards were $(\mathrm{kDa})$ : lysozyme, $14.3 ; \beta$-lactoglobulin, 18.4; carbonic anhydrase, 29.0; ovalbumin, 43.0; bovine serum albumin, 68.0. TrpB is indicated by an arrow (lane 3).

antisera directed against this organism (data not shown). One of these clones contained a plasmid with a $1.8 \mathrm{kbp}$ insert which was designated pOP43-2G. Using E. coli $\mathrm{DH} 5 \alpha$ as a host, we were unable to detect the protein(s) encoded by the insert by SDS-PAGE and immunoblot analysis, suggesting that this strain was not suitable for expression of the cloned genes (data not shown). In addition, we were unable to detect the protein(s) encoded by the insert in in vitro-grown $P$. multocida P1059 when grown in BHI broth (Fig. 1, lane 1). However, when we used E. coli CSR603 maxicells transformed with pOP43$2 \mathrm{G}$, we detected a $43 \mathrm{kDa}$ protein by immunoblot analysis (Fig. 1, lane 3). This protein, subsequently identified as tryptophan synthase $\beta$-subunit ( $\operatorname{TrpB})$, was not expressed by E. coli CSR603 (Fig. 1, lane 2 ) nor by in vivo-grown $P$. multocida (Fig. 1, lane 4). While equal amounts of protein were loaded onto the polyacrylamide gel, there appeared to be fewer immunoreactive proteins in the in vivo-grown (Fig. 1, lane 4) versus in vitro-grown (Fig. 1, lane 1) cells. We have routinely observed this phenomenon following immunoblot analyses comparing protein extracts from cells grown under these conditions, although the cause is unknown. However, the antiserum used to develop these immunoblots was produced against in vitro-grown $P$. multocida, so one might expect to see stronger and more specific reactions with in vitro- rather than in vivo-grown cells. It has also been suggested that capsule, present only in the in vivo-grown cells, may mask potential antigenic determinants (Neera Galagedera, personal communication). These results suggest that expression of the $\operatorname{tr} p B$ gene in P. multocida differs between in vivo- and in vitro- 


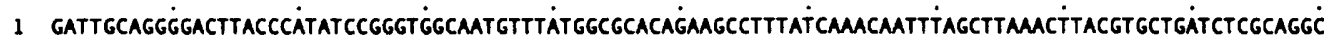

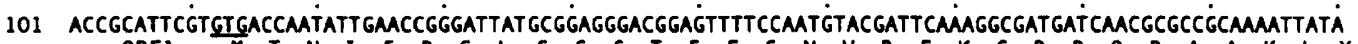
ORFI. $T$ T I E P G L C G G T E F S N V R F K G D D Q R A A K L Y

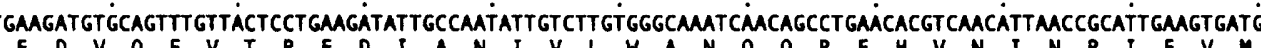
E D V Q

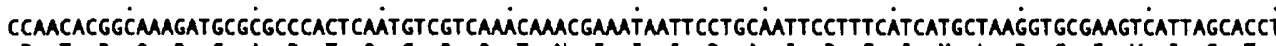
$P T R$ Q R C A P T Q C R Q T N E I I P A I P F I M L R C E V I S T

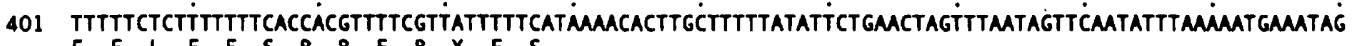
F F L F F S P R F R Y F S

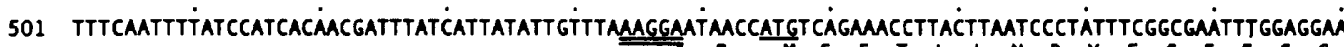
TrPB - H S E T L L N P Y F G E F G G

601 TGTATGTCCCCGAMATTCTGATGCCGGTGTTG GMAMATCTCGAMMGGCCTTTGTTGAGGCACMCAMGATCCCCACATTTAMAGAMACCTTCCTCGATTT $M Y V P E I L M P V L K N L E K A F V E A Q Q D P T F K E T F L D L$

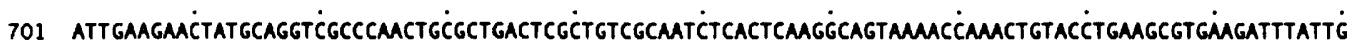
$L K N$ K A G R P T A L T R C R N L T Q G S K T K L Y L K R E D $L L$

801 CATGGCGGTGCGCATMMACCMATCMGTATTAGGGCAMATCTTATTAGCGAMCGGATGGGCAMUCCCGTATTATTGCGGGMACAGGGGCGGGACMAC H G G A H K T N Q V L G Q I L L A K R M G K T R I I A E T G A G Q

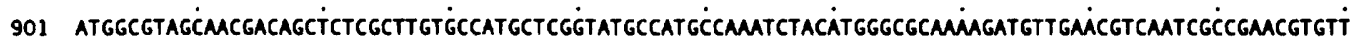
H G V A T T A L A C A M L G M P C Q I Y M G A K D V E R Q S P N V F

1001 TCGTATGCGTTTMTGGGGGCGMTGTGACTGGGGTAMCGMMGGGCTCAGCCTCATTMMinGATGCCTGCTGGTGAGGCCATGCGCGATTGGGCAGMMAC R M R L M G A N V T A V T K G S A S L L K D A C C E E A M R D N A E N

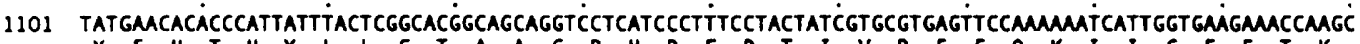
$Y E$ H T H Y L L G T A A G P H P F P T I V R E F Q K I I G E E T K

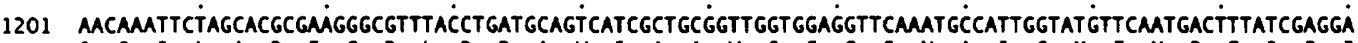
$Q$ Q I L A R E G R L P D A V I A A V G G G S N A I G M F N D F I E E

1301 AACTAGCGTACGTTTMTTGGTGTTGMCCAGCGGGCMAGGAATTGCCACTGGGCMACATGGCGCTCCACTAGGTCATGGCACMACGGGAMTCTATTTT T S V R L I G V E P A G K G I I A T G Q H

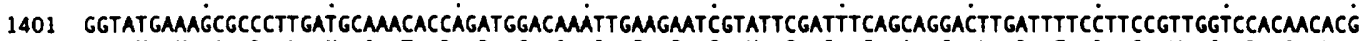

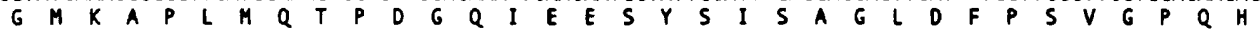

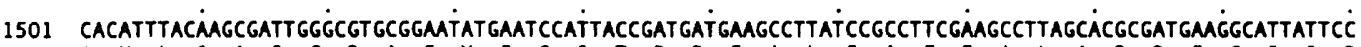
A H L Q A I G R A E Y E S I T D D E A L S A F E A L A R D E G I I P

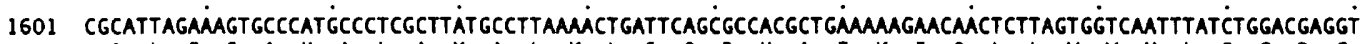
$A L E S A$ A A L A Y A L K L I Q R H A E K E Q L L V V N L S G R G

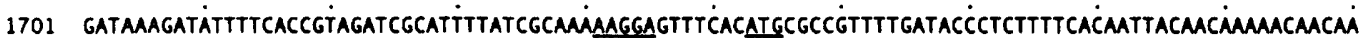
$D K D I F T V D R I L S Q \bar{K} G V S$ G $A P F$ trpA. " M R R F D T L F S Q L Q Q K Q Q.

Fig. 2. Nucleotide and amino acid sequences of $P$. multocida $\operatorname{trp} B$ and the $5^{\prime}$-end of trpA. The DNA sequence was determined from both strands as described in Methods. The deduced amino acid sequence is given in the single-letter code below the nucleotide sequence. Start codons are single-underlined. ORF1 comprises nucleotides 112-438. The 5'-end of $\operatorname{trp} B$ (nt 555-1767) is indicated and the $3^{\prime}$-end of the gene is indicated by $\bullet \bullet \bullet$. The putative Shine-Dalgarno sequence upstream of the predicted ATG initiation codon is double-underlined. The 5 -end of the gene encoding trpA is indicated (nt 1753-1830). The putative Shine-Dalgarno sequence upstream of the predicted ATG initiation codon of the trpA gene is double-underlined.

grown cells. It is well known that $\operatorname{TrpB}$ is located in the cytoplasm, which raises the question as to why this intracellular protein is a prominent antigen in $P$. multocida. We can speculate that since $P$. multocida is cleared from the bloodstream and eventually lysed in the liver and other organs, intracellular proteins may be released and thus become suitable antigens despite their original cellular location.

The nucleotide sequence of the $1.8 \mathrm{kbp}$ insert of pOP43$2 \mathrm{G}$ was determined on both strands, and revealed three potential open reading frames (ORFs) (Fig. 2). ORF1 (nt 12-438) is 327 nucleotides long and is upstream of ORF2. Computer analysis of the DNA and the deduced amino acid sequences did not reveal significant similarity to any gene or protein in the nonredundant nucleic acid or protein databases of NCBI. ORF2 (nt 555-1767) is 1209 nucleotides long and could potentially encode a protein of 403 amino acids (Fig. 2). Analysis of the DNA sequence revealed high similarity with the tryptophan synthase $(\operatorname{tr} p B)$ genes from several strains of bacteria. This ORF was thus designated $\operatorname{tr} p B$. The gene encoding $\operatorname{TrpB}$ starts with an ATG start codon and ends with a TGA termination codon. This termination codon overlaps the ATG initiation codon of ORF3 by 14 nucleotides. The putative product of the $P$. multocida $\operatorname{tr} p B$ gene (43662 Da) showed $77 \%$ identity ( $84 \%$ similarity) with the tryptophan synthase $\beta$ subunit of Salmonella typhimurium (Fig. 
(a)

P. $m$. MSETLLNPYFGEFGGMYVPEILMPVLKNLEKAFVEAQQDPTFKETFLDLL -50 S. $t$ M-TTLLNPYFGEFGGMYVPILMPALNQLEEAFVRAQKDPEFQAQFADLL -49

P. $m$. KNYAGRPTALTRCRNLTQGSKTKLYLKREDLL HGGAHKTNQVLGOILLAK - 100 S. $t$ KNYAGRPTALTKCQNITAGTRTTLYLKREDLLHGGAHKTNQVLGQALLAK -99

P. m. RMGKTR IIAETGAGOHGVATTALACAMLGMPCQIYMGAKDVERQSPNVFR - 150 s. $t$ RMGKSEIIAETGAGQHGVA-SALASALLGLKCRIYMGAKDVERQSPNVFR - 148

P. $m$. MRLMGANVTAVTKGSASLKDACCEAMRDWAENYEHTHYLLGTAAGPHPFP -200

S. $t$ MRLMGAEVIPVHSGSATLKDACNEALRDWSGSYETAHYMLGTAAGPHPYP -198

P. $m$. TIVREFQKIIGEETKQQI LAREGRLPDAVIAAVGGGSNAIGMFNDFIEET -250

S. $t$ TIVREFQRMIGEETKAQILDKEGRLPDAVIACVGGGSAIGMFADFINDT -248

P. $m$. SVRLIGVEPAGKGIATGQHGAPLGHGTTGIYFGMKAPLMQTPDGQIEESY - 300 S. $t$ SVGLIGVEPGGHGIETGEHGAPLKHGRVGIYFGMKAPMMQTADGQIEESY -298

P. m. SISAGLDFPSVGPQHAHLQAIGRAEYESITDDEALSAFEALARDEGIIPA - 350

s. $t$ SISAGLOFPSVGPQHAYLNSIGRADYVSITDDEALEAFKTLCRHEGIIPA -348

P. m. LESAHALAYALKLIQRHAEKEQLLVVNLSGRGDKDIFTVDRILSQKGVSH -400 S. t. LESSHALAHALKMMREQPEKEQLIVWNLSGRGDKDIFTVHDILKARG-- - -395

P. m. APF -403

S. t. $-E I-397$

(b)

P. m. MRRFDTLFSQLQQKQQGAFVPFVTL -578

K. a. MERYETLFAQLKNRQEGAFVPFVTL -25

Fig. 3. Comparison of the predicted amino acid sequences of the TrpB and TrpA subunits. (a) Comparison of the deduced amino acid sequences of TrpB from P. multocida (top line) and $S$. typhimurium (bottom line). The eight conserved regions found in TrpB proteins are double-underlined. (b) Comparison of the deduced amino acid sequences of TrpA from $P$. multocida (top line) and $K$. aerogenes ( $K$. pneumoniae) (bottom line). (:) indicates identical amino acid residues. In both comparisons, alignment was determined using the sequence alignment programs of PC-Gene.

3a) and Vibrio parabaemolyticus. Comparison of the $P$. multocida tryptophan synthase deduced amino acid sequence with other TrpB sequences showed significant identity (ranging from 50 to $77 \%$ ) as well as similarity (64 to $84 \%$ ). This is not surprising, since within the tryptophan biosynthetic operon, TrpB sequences have the highest similarity. To confirm the identity of the gene product we complemented an E. coli $\operatorname{trp} B$ mutant (strain W3110 tna $A 2 \operatorname{trp} B 9578)$, restoring it to tryptophan prototrophy (data not shown).

The $P$. multocida tryptophan synthase $\beta$ subunit shares several features in common with other tryptophan synthases. Every bacterial tryptophan synthase examined to date contains eight conserved regions (Crawford, 1989). These regions are also found in the P. multocida $\operatorname{TrpB}$ (Fig. 3 ). The amino acid residues important for catalysis have been assigned from the results of site-directed mutagenesis from other bacteria (Miles et al., 1989; Nagata et al., 1989; Yutani et al., 1987) and the three-dimensional structure (Hyde et al., 1988) of the S. typhimurium tryptophan synthase. Pre-eminent among these residues is Lys- 88 (numbers for the $P$. multocida subunit), which forms a Schiff base with the coenzyme pyridoxal phosphate. Gly234 to Ala-239 form a pocket for the phosphate group of the coenzyme. Ser-379 and Gly-380 bind other parts of the coenzyme molecule. Glu-110 and His-116 are involved in binding the L-serine substrate.

The $\mathrm{G}+\mathrm{C}$ content $(\mathrm{mol} \%)$ of the coding regions of $P$. multocida $\operatorname{tr} p B$ is $46.3 \%$, with $28.6 \%$ A, $22.8 \%$ C, $23.5 \%$ $\mathrm{G}$ and $24.9 \% \mathrm{~T}$. This is comparable to that of the whole $P$. multocida genome $(36-43 \mathrm{~mol} \% \mathrm{G}+\mathrm{C})$, but is higher than that of the P. multocida toxin gene $(34.4 \mathrm{~mol} \%)$; this may reflect different evolutionary origins between normal housekeeping genes and virulence factors in this organism. Despite the high level of similarity between the $S$. typhimurium and $P$. multocida genes, codon usage is biased between the two organisms, particularly with codons for leucine, isoleucine, and glutamine.

In addition to $\operatorname{trp} B$, the $1.8 \mathrm{kbp}$ fragment of pOP43-2G contains the first 77 nucleotides of the $5^{\prime}$-end of the gene (nt 1753-1830) encoding the $\alpha$-subunit of the tryptophan synthase (TrpA) of P. multocida (Fig. 2). The deduced amino acid sequence has $68 \%$ identity ( $92 \%$ similarity) with TrpA of Klebsiella aerogenes (K. pneumoniae) (Fig. 3b). The start codon for $\operatorname{tr} p A$ is found 14 nucleotides upstream within the $3^{\prime}$-end of $\operatorname{tr} p B$ (Fig. 2). There does not appear to be any other gene of the tryptophan operon within 555 nucleotides upstream of $\operatorname{tr} p B$. In $E$. coli there is an 11 nucleotide spacer between the $\operatorname{tr} p C$ stop codon and the $\operatorname{trpB}$ start codon (Yanofsky et al., 1981), while in Lactococcus lactis there is a 585 nucleotide spacer between the $\operatorname{trpF}$ and $\operatorname{trp} B$ genes (Bardowski et al., 1992). Both genes contain putative ribosome-binding sites (RBS) with sequences of AAGGA (Fig. 2). Comparison of the putative RBS of the $P$. multocida $\operatorname{trp} B$ and $\operatorname{trp} A$ genes revealed perfect similarity with only the RBS of the gene encoding the $\beta$-lactamase from $P$. baemolytica (Livrelli et al., 1991).

The identification of the $43 \mathrm{kDa}$ protein examined here as a tryptophan synthase offers a potential explanation of why we were unable to detect this protein when $P$. multocida was grown in rich medium. When $E$. coli is grown in rich medium containing high levels of tryptophan, the tryptophan synthase is repressed; however, when tryptophan is lowered to a specific level, activity is derepressed. The growth of $P$. multocida in a defined medium in which the level of tryptophan can be regulated may provide further information on the regulation of the synthesis of this protein.

The interruption of aro $A$ in $P$. multocida results in a highly attenuated mutant (Homchampa et al., 1992). Given the 
fact that the enzyme encoded by this gene is involved in the synthesis of aromatic amino acids, one may speculate that interruption of $P$. multocida $\operatorname{tr} p B$ gene may also result in an attenuated mutant. Little is known about amino acid metabolism in the Pasteurellaceae and how it may be involved in virulence. Future work on $\operatorname{tr} p B$ will assess the specific suitability of $\operatorname{tr} p B$ mutants of $P$. multocida as live attenuated vaccines against fowl cholera.

\section{ACKNOWLEDGEMENTS}

We thank Dr Charles Yanofsky for providing the $\operatorname{tr} p B$ mutant used in this study and also Drs Gerhart Schurig and Steven Boyle of Virginia Tech for helpful comments related to this work. We also thank Drs Phil Youderian and Scott Minnich at the University of Idaho for helpful suggestions, and Neera Galagedera (Virginia Tech) for production of the in vivo antigen preparation. Special thanks are extended to Aline Click at Northern Illinois University for help with preparation of figures.

\section{REFERENCES}

Altschul, S. F., Gish, W., Miller, W., Myers, E. W. \& Lipman, D. J. (1990). Basic local alignment search tool. J Mol Biol 215, 403-410.

Ausubel, F. M., Brent, R., Kingston, R. E., Moore, D. D., Seidman, J. G., Smith, J. A. \& Struhl, K. (1989). Short Protocols in Molecular Biology. New York: Wiley-Interscience.

Bardowski, J., Ehrlich, S. D. \& Chopin, A. (1992). Tryptophan biosynthesis genes in Lactococcus lactis subsp. lactis. J Bacteriol 174, 6563-6570

Bollag, D. M. \& Edelstein, S. J. (1991). Protein Methods. New York: Wiley-Liss

Crawford, I. P. (1989). Evolution of a biosynthetic pathway: the tryptophan paradigm. Annu Rev Microbiol 43, 567-600.

Creighton, T. E. \& Yanofsky, C. (1966). Association of the $\alpha$ and $\beta_{2}$ subunits of the tryptophan synthetase of Escherichia coli.J Biol Chem 241, 980-990.

Dower, W. F., Miller, F. \& Ragsdale, C. W. (1988). High efficiency transformation of Escherichia coli by high voltage electroporation. Nucleic Acids Res 16, 6127-6145.

Hanahan, D. (1983). Studies on transformation of Escherichia coli with plasmids. $J$ Mol Biol 166, 557-580.

Hansen, L. M. \& Hirsh, D. C. (1989). Serum resistance is correlated with encapsulation of avian strains of Pasteurella multocida. Vet Microbiol 21, 177-184.

Homchampa, P., Strugnell, R. A. \& Adler, B. (1992). Molecular analysis of the aro $A$ gene of Pasteurella multocida and vaccine potential of a constructed aro $A$ mutant. Mol Microbiol 6, 3585-3593.

Hu, S. P., Felice, L. J., Sivanandan, V. \& Maheswaran, S. K. (1986). Siderophore production by Pasteurella multocida. Infect Immun 54, 804-810.

Hyde, C. C., Ahmed, S. A., Padlan, E. A., Miles, E. W. \& Davies, D. R. (1988). Three dimensional structure of the tryptophan synthetase $\alpha 2 \beta 2$ multienzyme complex from Salmonella typhimurium. J Biol Chem 263, 17857-17871.

Laemmli, U. K. (1970). Cleavage of structural proteins during the assembly of the head of bacteriophage T4. Nature 227, 680-685.

Lax, A. J., Chanter, N., Pullinger, G. D., Higgins, T., Staddon, J. M. \& Rozengurt, E. (1990). Sequence analysis of the potent mitogenic toxin of Pasteurella multocida. FEBS Lett 277, 59-64.
Livrelli, V., Peduzzi, J. \& Joly, B. (1991). Sequence and molecular characterization of the ROB-1 beta-lactamase gene from Pasteurella baemolytica. Antimicrob Agents Chemother 35, 242-251.

Lu, Y. S., Aguila, H. N., Lai, W. C. \& Pakes, S. P. (1991a). Antibodies to outer membrane proteins but not to lipopolysaccharide inhibit pulmonary proliferation of Pasteurella multocida in mice. Infect Immun 59, 1470-1475.

Lu, Y. S., Lai, W. C., Pakes, S. P. \& Nie, L. C. (1991b). A monoclonal antibody against a Pasteurella multocida outer membrane protein protects rabbits and mice against pasteurellosis. Infect Immun 59, $172-180$.

Manoha, F., Chevalier, G., Wróblewski, H. \& Delamarche, C. (1994). Cloning and expression of two Pasteurella multocida genes in Escherichia coli. Biocbimie 76, 9-14.

Miles, E. W., Kawasaki, H., Ahmed, S. A., Morita, H., Morita, H. \& Nagata, S. (1989). The $\beta$ subunit of tryptophan synthase. $J$ Biol Chem 264, 6280-6287.

Mock, M., Crasnier, M., Duflot, E., Dumay, V. \& Danchin, A. (1991). Structural and functional relationships between Pasteurella multocida and enterobacterial adenylate cyclases. $J$ Bacteriol 173, 6265-6269.

Murray, M. G. \& Thompson, W. F. (1980). Rapid isolation of high molecular weight plant DNA. Nucleic Acids Res 8, 4321-4325.

Nagata, S., Hyde, C. C. \& Miles, E. W. (1989). The $\alpha$ subunit of tryptophan synthase. J Biol Chem 264, 6288-6296.

Petersen, S. K. (1990). The complete nucleotide sequence of the Pasteurella multocida toxin gene and evidence for a transcriptional repressor, TxaR. Mol Microbiol 4, 821-830.

Petersen, S. K. \& Foged, N. T. (1989). Cloning and expression of the Pasteurella multocida toxin gene, tox $A$, in Escherichia coli. Infect Immun 57, 3907-3913.

Pohl, S. (1981). Pasteurella multocida. In Haemopbilus, Pasteurella, and Actinobacillus, pp. 245-254. Edited by K. Killian, W. Fredericksen \& E. L. Biberstein. London: Academic Press.

Rhoades, K. R. \& Rimler, R. B. (1987). Effects of Pasteurella multocida endotoxins on turkey poults. Avian Dis 31, 523-526.

Rhoades, K. R. \& Rimler, R. B. (1988). Toxigenicity and virulence of capsular serogroup D Pasteurella multocida strains isolated from turkeys. J Am Vet Med Assoc 192, 1790.

Rimler, R. B. \& Rhoades, K. R. (1981). Lysates of turkey-grown Pasteurella multocida: protection against homologous and heterologous serotype challenge exposures. Am J Vet Res 42, 2117-2121.

Rimler, R. B. \& Rhoades, K. R. (1989). Pasteurella multocida. In Pasteurella and Pasteurellosis, pp. 37-73. Edited by C. Adlam \& J. M. Rutter. London: Academic Press.

Sambrook, J., Fritsch, E. F. \& Maniatis, T. (1989). Molecular Cloning: a Laboratory Manual, 2nd edn. Cold Spring Harbor, NY: Cold Spring Harbor Laboratory.

Sanger, F., Nicklen, S. \& Coulson, A. R. (1977). DNA sequencing with chain-terminating inhibitors. Proc Natl Acad Sci USA 74, 5463-5467.

Snipes, K. P., Ghazikhanian, G. Y. \& Hirsh, D. C. (1987). Fate of Pasteurella multocida in the blood vascular system of turkeys following intravenous inoculation: comparison of an encapsulated, virulent strain with its avirulent, acapsular variant. Avian Dis 31, 254-259.

Towbin, H., Staehelin, T. \& Gordon, J. (1979). Electrophoretic transfer of proteins from polyacrylamide gels to nitrocellulose sheets: procedure and some applications. Proc Natl Acad Sci USA 76, 4350-4354.

Truscott, W. M. \& Hirsh, D. C. (1988). Demonstration of an outer 
membrane protein with antiphagocytic activity from Pasteurella multocida of avian origin. Infect Immun 56, 1538-1544.

Wijewardana, T. G., Wilson, C. F., Gilmour, N. J. \& Poxton, I. R. (1990). Production of mouse monoclonal antibodies to Pasteurella multocida type $A$ and the immunological properties of a protective anti-lipopolysaccharide antibody. J Med Microbiol 33, 217-222.

Wilson, D. A. \& Crawford, I. P. (1965). Purification and properties of the B component of Escherichia coli tryptophan synthetase. J Biol Chem 240, 4801-4808.

Yanofsky, C., Platt, T., Crawford, I. P., Nichols, B. P., Christie,
G. E., Horowitz, H., VanCleemput, M. \& Wu, A. M. (1981). The complete nucleotide sequence of the tryptophan operon of Escherichia coli. Nucleic Acids Res 9, 6647-6668.

Yutani, K., Ogasawara, K., Tsujita, T., Kanemoto, K., Matsumoto, M., Tanaka, S., Miyashita, T., Matsushiro, A., Sugino, Y. \& Miles, E. W. (1987). Tryptophan synthase $\alpha$ subunit glutamic acid 49 is essential for activity. J Biol Chem 262, 13429-13433.

Received 18 May 1995; revised 2 September 1995; accepted 20 September 1995. 